\title{
Coconut Coir Dust Extract (CCDE) as green corrosion inhibitor for rebar' steel in concrete environment
}

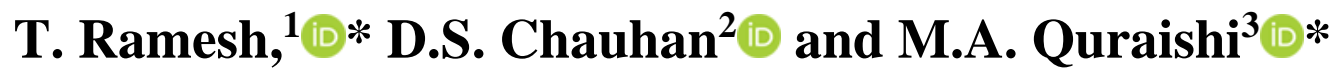 \\ ${ }^{1}$ Department of Civil Engineering, PSG College of Technology, Coimbatore-641 004, \\ Tamilnadu, India \\ ${ }^{2}$ Modern National Chemicals, Second Industrial City, Dammam 31421, Saudi Arabia \\ ${ }^{3}$ Interdisciplinary Research Center for Advanced Materials, King Fahd University of \\ Petroleum and Minerals, Dhahran 31261, Saudi Arabia \\ *E-mail: ram.civil@psgtech.ac.in; maquraishi.apc@itbhu.ac.in
}

\begin{abstract}
Corrosion of reinforcement steel in concrete is one of the drawbacks of reinforced concrete structures. An attempt is made to use Coconut Coir Dust Extract (CCDE) as a green corrosion inhibitor. The efficacy of the CCDE is examined in simulated concrete pore solutions and in concrete structures. The influence of CCDE on the inhibition of corrosion of steel in concrete has been evaluated by non-electrochemical and electrochemical techniques. The various concentrations of CCDE $(0 \%, 10 \%, 20 \%, 30 \%$ and $40 \%)$ in simulated concrete pore solution (SCPS with $3.5 \% \mathrm{NaCl}$ ) were studied by weight loss, potentiodynamic polarization and electrochemical impedance spectroscopy. The addition of CCDE up to $40 \%$ did not affect the mechanical property of concrete. It is observed that CCDE was able to provide more than $95 \%$ inhibition efficiency in SCPS with $3.5 \% \mathrm{NaCl}$ solution. The mechanism of inhibition is due to adsorption and, thereby, film formation on the steel surface. Potentiodynamic polarization studies indicated that CCDE act as a mixed type inhibitor and predominantly cathodic. CCDE is a good candidate greener inhibitor for corrosion of steel in concrete because it increases the compressive strength of concrete and reduces the self-corrosion of steel rebar in chloride environment to the maximum extent.
\end{abstract}

Keywords: concrete, rebar, coconut coir dust extract, green corrosion inhibitor.

Received: December 21, 2020. Published: April 19, 2021

doi: $\underline{10.17675 / 2305-6894-2021-10-2-9}$

\section{Introduction}

Globally, corrosion of reinforcement is a serious problem in the construction industry. Many approaches are used to mitigate the corrosion of rebars in concrete, such as coating to rebar, cathodic protection, re-alkalization of the concrete, electrochemical removal of chloride from concrete, and corrosion inhibitors [1,2]. Among the methods listed, the use of corrosion inhibitors is considered an effective way of mitigating reinforcement corrosion [3-5]. A lot of literature is available on the use of corrosion inhibitors in concrete [6-12]. Reviews on the most commonly used inhibitors in concrete systems and their probable mechanism have been recently published [13-19]. In fact, calcium nitrite-based inhibitors 
are widely used as corrosion inhibitors worldwide [6]. In the next generation, the use of organic inhibitors is an alternative way to calcium nitrite-based inhibitor [14]. Organic corrosion inhibitors are able to adsorb and forming a barrier film on the steel surface [15]. Duprat and Dabosi examined the effect of various amino alcohols as corrosion inhibitors for carbon steel in $3.5 \% \mathrm{NaCl}$ solution.

Recently, the use of green corrosion inhibitors in the construction industry is coming into existence in order to satisfy our demands [20,21]. Actually, green corrosion inhibitors are extracted from the plant products such as bark, leaf, seed, fruit, roots, etc. Green corrosion inhibitors are biodegradable. They do not contain heavy metals or other toxic compounds [17]. Some research groups have reported the successful use of naturally occurring substances to inhibit the corrosion of metals in acidic and alkaline environments. The coconut coir dust which is a by-product in the coir industry, is used by Saviour A. Umoren et al. (2014) [19] and reported that the coconut coir dust extract obtained from a solvent system is inhibiting steel corrosion.

Coconut coir dust extract (CCDE) was used as a green corrosion inhibitor in this study. Palanisamy et al. [18] highlighted natural products/biomaterials of plant origin that have been reported as corrosion inhibitors for metals in corrosive media. In the extraction of coir fiber from the coconut husk and in the production of finished materials from the extracted fiber, a large amount of coir dust is produced. Coir dust is rich in lignins, alkaloids, and tannins. It is reported to be composed of cellulose, pentosane, furfural, lignin [19]. Hence, the present study utilizes CCDE as a possible green corrosion inhibitor for steel in concrete. The objectives of the current investigation are as follows:

The inhibitive performance of CCDE is examined in simulated concrete pore solution (SCPS) $+3.5 \% \mathrm{NaCl}$ with varying percentage of $\mathrm{CCDE}(0 \%, 10 \%, 20 \%, 30 \%$ and $40 \%)$.

The influence of $\mathrm{CCDE}$ on the mechanical and corrosion-resistant properties of concrete with varying percentages of $\operatorname{CCDE}(0 \%, 10 \%, 20 \%, 30 \%$, and $40 \%)$ was studied.

\section{Materials and Methods}

\subsection{Materials used}

\subsubsection{Cement and aggregates}

Portland Pozzolana cement (PPC) was used throughout this investigation. Manufactured sand (M-sand) was used as fine aggregate with specific gravity 2.73 conforming to zone II of IS 456:2000. A coarse aggregate of maximum size $20 \mathrm{~mm}$ with a specific gravity of 2.85 was used. M30 grade of concrete was designed as per Indian Standard. Thermomechanically treated (TMT) rebar of size $16 \mathrm{~mm}$ diameter and $12 \mathrm{~cm}$ length was used.

\subsubsection{Preparation of coconut coir dust extract (CCDE)}

The coir dust was collected from the coir industry located in Pollachi, Tamilnadu, India. As received, coir dust was immersed in distilled water for 72 hours. During this period, the coir 
dust was paddled at regular intervals of time. After 72 hours, CCDE was obtained by filtration. This filtrate was used for casting concrete specimens and further examinations. Structures of some commonly occurring alkaloids and flavonoids is shown in Figure 1.

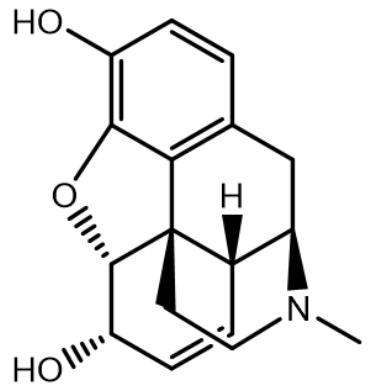

morphine

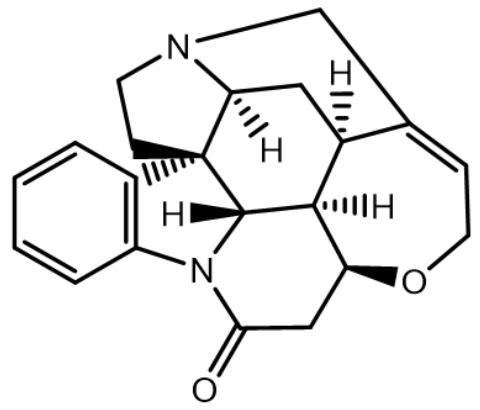

strychnine

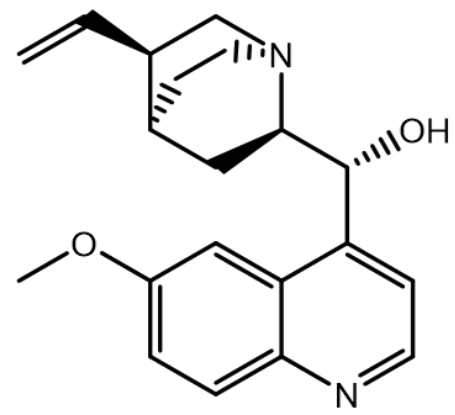

quinine

Alkaloids<smiles>Oc1cc(O)c2c(c1)OC(c1ccc(O)c(O)c1)C(O)C2</smiles>

catechin<smiles>O=c1cc(-c2ccc(O)cc2)oc2cc(O)cc(O)c12</smiles>

apigenin

Flavonoids

Figure 1. Structures of some common alkaloids and flavonoids present in plants.

\subsubsection{Preparation of simulated concrete pore solution (SCPS)}

SCPS was prepared using $34 \mathrm{~g}$ of $\mathrm{KOH}$ and $25 \mathrm{~g}$ of $\mathrm{NaOH}$ in one litre of saturated $\mathrm{Ca}(\mathrm{OH})_{2}$ solution [22]. Studies were carried out in SCPS with $3.5 \% \mathrm{NaCl}$.

\subsubsection{Preparation of concrete specimens}

Reinforced cylindrical concrete specimens of size $10 \mathrm{~cm}$ diameter and $15 \mathrm{~cm}$ height were cast. Rebar of size $16 \mathrm{~mm}$ diameter and length $12 \mathrm{~cm}$ was centrally placed in the specimen. $2 \mathrm{~cm}$ length of rebar exposed to the environment is coated with epoxy, and the remaining $10 \mathrm{~cm}$ length is embedded in concrete. M30 grade of concrete with a w/c ratio of 0.4 was designed. Specimens were cast with 10\%, 20\%, 30\%, and 40\% of CCDE by weight of water in the actual w/c ratio. The specimen details are given in Table 1. The concrete specimens were subjected to a curing period of 28 days in normal water and subjected to alternate wet and dry cycle in $3.5 \% \mathrm{NaCl}$ solution for another 30 days. 
Table 1. Mix designation for concrete with various proportions of CCDE.

\begin{tabular}{rc}
\hline Mix designation & System \\
\hline M30CM00 & Control Specimen \\
M30CM10 & $10 \% \mathrm{CCDE}$ \\
M30CM20 & $20 \% \mathrm{CCDE}$ \\
M30CM30 & $30 \% \mathrm{CCDE}$ \\
M30CM40 & $40 \% \mathrm{CCDE}$ \\
\hline
\end{tabular}

\subsection{Mechanical property: Compressive strength of concrete}

A compressive strength test was carried out as per IS-516-1959 in concrete cubes of size $150 \times 150 \times 150 \mathrm{~mm}$ using a designed mix of M30 with a w/c ratio of 0.40 . The cured specimens were tested for compressive strength using the AIMIL Compression testing machine of $2000 \mathrm{kN}$ capacity at a rate of loading of $140 \mathrm{kN} /$ minute. The test was carried out on triplicate specimens, and the average compressive strength values were recorded.

\subsection{Corrosion rate by weight loss measurement}

Triplicate steel rebar specimens were immersed in SCPS with $3.5 \% \mathrm{NaCl}$ by varying the percentage of $\operatorname{CCDE}(0 \%, 10 \%, 20 \%, 30 \%$, and $40 \%)$. The corrosion rate of rebar specimen in mmpy for an exposure period of 90 days was calculated as reported elsewhere [23].

\subsection{Electrochemical studies}

\subsubsection{Open circuit potential measurements}

The potential time behavior of steel in SCPS with $3.5 \% \mathrm{NaCl}$ and in concrete specimens prepared as specified earlier was periodically monitored using a high impedance voltmeter (20 M $\Omega$ ) for an exposure period of 90 days. The experimental setup for performing the electrochemical corrosion tests is shown in Figure 2.

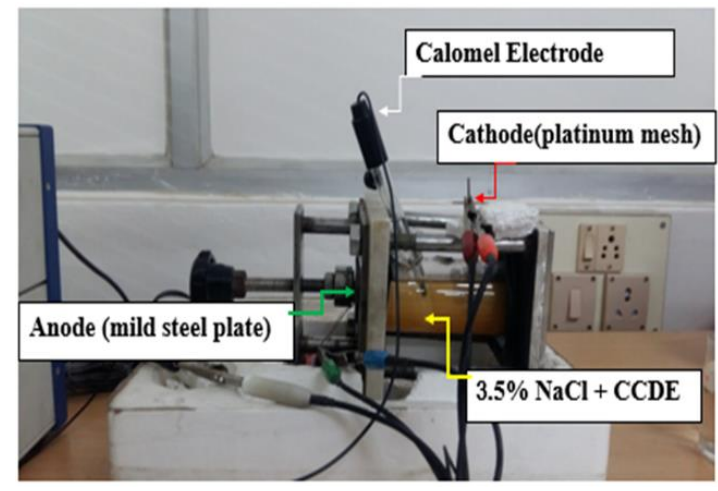

Figure 2. Experimental setup for corrosion study. 


\subsubsection{Potentiodynamic polarization studies}

Potentiodynamic polarization studies were carried out for steel in SCPS with $3.5 \% \mathrm{NaCl}$ by varying the percentage of $\operatorname{CCDE}(0 \%, 10 \%, 20 \%, 30 \%$, and $40 \%)$. Three electrode glass cell assembly was used for this study. Rebar sample was served as a working electrode, platinum foil of larger area was used as the counter electrode, and saturated calomel electrode (SCE) was served as the reference electrode. The potentiodynamic conditions correspond to $\pm 250 \mathrm{mV} v s$. SCE. The sweep rate was $1 \mathrm{mV} / \mathrm{s}$. Both cathodic and anodic polarization curves were recorded using a Gamry Electrochemical workstation. This instrument itself has provision for calculating the corrosion kinetic parameters such as $E_{\text {corr. }}$, $I_{\text {corr. }}, \beta_{\mathrm{a} \text {, and }} \beta_{\mathrm{c}}$. All the experiments were carried out at a room temperature of $30 \pm 1^{\circ} \mathrm{C}$.

Potentiodynamic polarization studies were carried out for rebar embedded in concrete with different proportions of CCDE inhibitors. Here rebar embedded in the concrete act as working electrode, platinum foil acted as counter electrode and SCE act as a reference electrode. The other conditions remain the same as stated for solution studies.

\subsubsection{AC-Impendence spectra}

The same three-electrode cell assembly was used here also. Nyquist Plot was recorded in the frequency range from $10 \mathrm{mHz}$ to $100 \mathrm{kHz}$ using a frequency response analyzer. The charge transfer resistance was obtained from the difference between initial and final frequency. The double-layer capacitance values were measured with maximum frequency using the following formula $C_{\mathrm{dlma}}=1 /\left(2 \pi R_{\mathrm{ct}}\right)$. All the experiments were carried out at a room temperature of $30 \pm 1{ }^{\circ} \mathrm{C}$.

\subsection{Surface examination by FTIR Spectra}

After the exposure period, the concrete specimen is split open, and the steel-concrete interface was subjected to FTIR spectra by using Bruker Optik GmbH, Germany, with the spectral range 400 to $4000 \mathrm{~cm}^{-1}$.

\section{Results and Discussion}

\subsection{Compressive strength measurements}

The compressive strength data for concrete with varying percentages of CCDE is given in Table 2. From the table, it was observed that the average compressive strength of concrete with varying percentages of CCDE was found to be above $30 \mathrm{MPa}$, which is actually designed strength. The percentage variation in increase of compressive strength compared to control specimen for 10\%, 20\%, 30\% and 40\% CCDE are 5.94\%, 13.15\%, 8.28\% and $8.04 \%$ respectively. Here it was interesting to note that the addition of inhibitor CCDE does not reduce the compressive strength of concrete; rather, it will slightly increase the compressive strength of concrete. Here it was concluded that the addition of CCDE in the concrete formulation is beneficial with respect to concrete's mechanical properties. 
Table 2. Compressive strength data for concrete with varying percentage of CCDE.

\begin{tabular}{|c|c|c|c|c|c|c|c|c|c|}
\hline \multirow{2}{*}{ No. } & \multirow{2}{*}{$\begin{array}{c}\text { Mix } \\
\text { designation }\end{array}$} & \multirow{2}{*}{ Specimen } & \multicolumn{2}{|c|}{$\begin{array}{c}\text { Weight } \\
\text { (kg) }\end{array}$} & \multicolumn{2}{|c|}{$\begin{array}{l}\text { Load } \\
\text { (Ton) }\end{array}$} & \multicolumn{2}{|c|}{$\begin{array}{l}\text { Compressive } \\
\text { strength } \\
\text { (MPa) }\end{array}$} & \multirow{2}{*}{$\begin{array}{c}\begin{array}{c}\text { Average } \\
\text { compressive } \\
\text { strength } \\
\text { (MPa) }\end{array} \\
\text { Day } 28\end{array}$} \\
\hline & & & Day 7 & Day 28 & Day 7 & $\begin{array}{c}\text { Day } \\
28\end{array}$ & Day 7 & Day 28 & \\
\hline \multirow{3}{*}{1} & \multirow{3}{*}{ M30CM00 } & 1 & 8.84 & 8.75 & 52.0 & 74 & 22.67 & 32.26 & \multirow{3}{*}{34.29} \\
\hline & & 2 & 8.70 & 8.73 & 53.0 & 72 & 23.11 & 31.39 & \\
\hline & & 3 & 8.55 & 8.76 & 51.0 & 90 & 22.24 & 39.24 & \\
\hline \multirow{3}{*}{2} & \multirow{3}{*}{ M30CM10 } & 1 & 8.68 & 8.60 & 67.0 & 81 & 29.21 & 35.32 & \multirow{3}{*}{36.33} \\
\hline & & 2 & 8.71 & 8.63 & 65.0 & 84 & 28.34 & 36.62 & \\
\hline & & 3 & 8.89 & 8.78 & 59.0 & 85 & 25.72 & 37.06 & \\
\hline \multirow{3}{*}{3} & \multirow{3}{*}{ M30CM20 } & 1 & 8.36 & 8.84 & 55.0 & 81 & 23.98 & 35.32 & \multirow{3}{*}{38.88} \\
\hline & & 2 & 8.74 & 8.99 & 62.0 & 89 & 27.03 & 38.80 & \\
\hline & & 3 & 8.51 & 8.84 & 58.0 & 97 & 25.29 & 42.29 & \\
\hline \multirow{3}{*}{4} & \multirow{3}{*}{ M30СM30 } & 1 & 8.59 & 8.63 & 60.0 & 82 & 26.16 & 35.75 & \multirow{3}{*}{37.13} \\
\hline & & 2 & 8.62 & 8.76 & 60.0 & 89.5 & 26.16 & 39.02 & \\
\hline & & 3 & 8.73 & 8.69 & 61.0 & 84 & 26.60 & 36.62 & \\
\hline \multirow{3}{*}{5} & \multirow{3}{*}{ M30CM40 } & 1 & 8.68 & 8.76 & 66.0 & 89 & 28.76 & 38.80 & \multirow{3}{*}{37.05} \\
\hline & & 2 & 8.55 & 8.65 & 51.0 & 78 & 22.24 & 34.00 & \\
\hline & & 3 & 8.59 & 8.76 & 61.0 & 88 & 26.60 & 38.36 & \\
\hline
\end{tabular}

\subsection{Weight loss measurement}

The corrosion rate of rebar in SCPS with $3.5 \% \mathrm{NaCl}$ and embedded in concrete by varying the percentage of $\operatorname{CCDE}(0 \%, 10 \%, 20 \%, 30 \%$, and $40 \%)$ is given in Figure $3 \mathrm{a}$ and Figure $3 \mathrm{~b}$, respectively. The corrosion rate of steel in SCPS $+3.5 \% \mathrm{NaCl}$ without CCDE was $0.0537 \mathrm{mmpy}$. The corrosion rate of steel in SCPS $+3.5 \% \mathrm{NaCl}$ with $10 \%, 20 \%, 30 \%$, and $40 \% \mathrm{CCDE}$ were $0.0395 \mathrm{mmpy}, 0.0350 \mathrm{mmpy}, 0.0330 \mathrm{mmpy}$ and $0.0500 \mathrm{mmpy}$, respectively. Comparable corrosion rate with control specimen was observed up to $30 \% \mathrm{CCDE}$. Hence, the optimum level of CCDE with the better corrosion-resistant property was achieved at 30\% CCDE. The better inhibition of CCDE is due to the formation of a compact barrier film on the steel surface. The inhibitor CCDE able to inhibit the corrosion of steel in SCPS, even in the presence of $3.5 \% \mathrm{NaCl}$. This is due to the competitive adsorption of CCDE over the steel surface in the presence of chloride environments. Adsorption of inhibitor molecules leads to some of the attacking anions being rendered 
inactive. Further, the adsorption process promotes film formation. Hence the combined effect of adsorption and film formation maintains perfect passivity on the steel surface even in the presence of higher concentrations of aggressive ions.

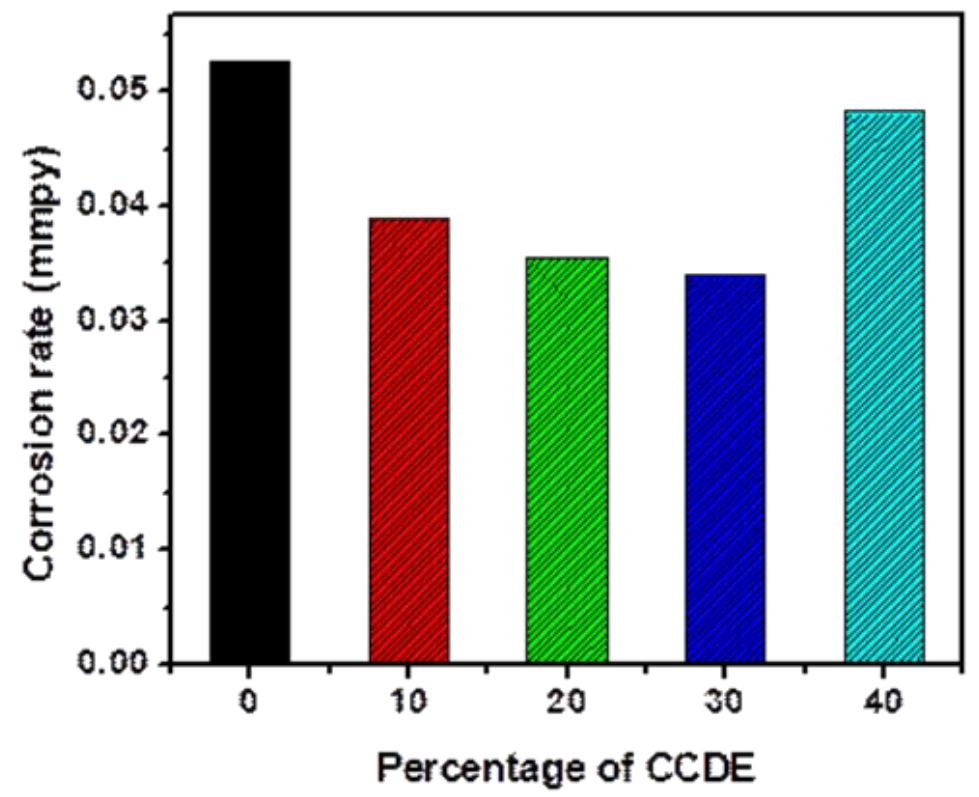

Figure 3a. Corrosion rate of steel in SCPS with varying percentage of CCDE.

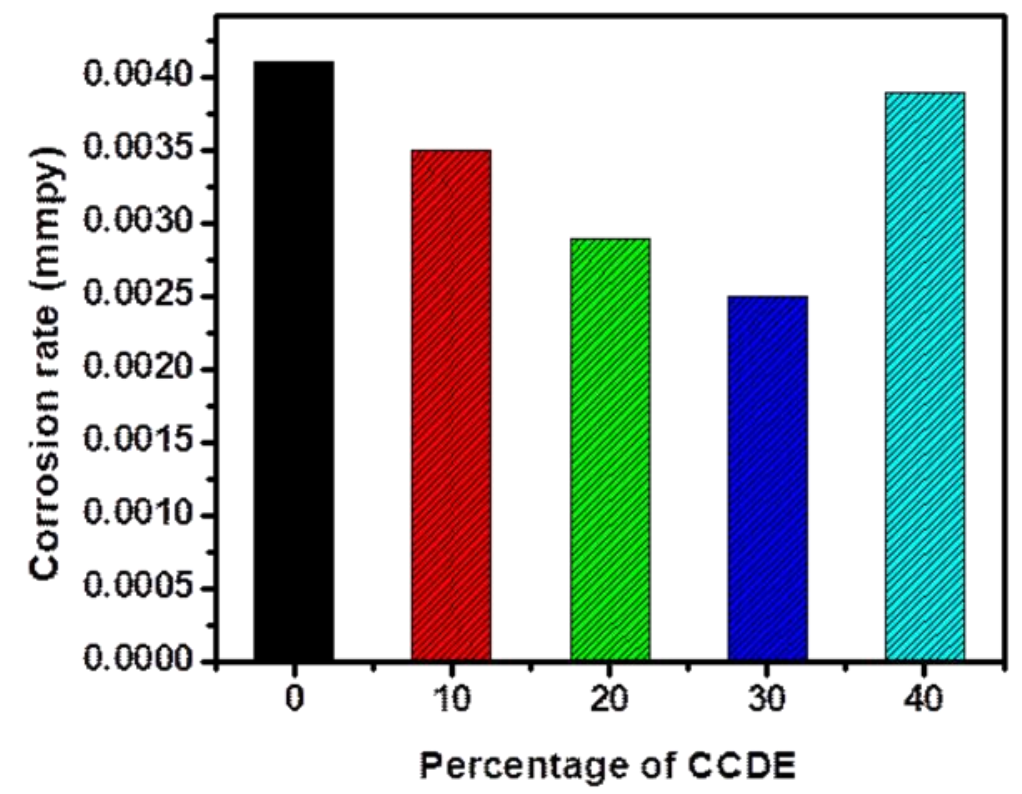

Figure 3b. Corrosion rate of steel in concrete with varying percentage of CCDE.

Similarly, the corrosion rate of steel in concrete without CCDE was $0.0042 \mathrm{mmpy}$. The corrosion rate of steel in concrete with 10\%, 20\%, 30\% and 40\% CCDE was 0.0035 mmpy, $0.0029 \mathrm{mmpy}, 0.0025 \mathrm{mmpy}$ and $0.0040 \mathrm{mmpy}$, respectively. Comparable corrosion rate 
with control specimen was observed up to $30 \%$ CCDE. CCDE contains organic molecules like lignin, tannins, etc., which contains an abundance of pi electrons and lone pair of electrons in $\mathrm{N}$ and $\mathrm{O}$ atom able to donate and sharing with vacant $\mathrm{d}$ orbital of $\mathrm{Fe}$, which provides better inhibition even in the higher concentration of chloride ions.

\subsection{Electrochemical studies in SCPS and concrete}

\subsubsection{Open circuit potential}

The potential-time behavior of rebar in SCPS $+3.5 \% \mathrm{NaCl}$ and embedded in concrete with various concentration of $\operatorname{CCDE}(0 \%, 10 \%, 20 \%, 30 \%$ and $40 \%)$ is shown in Figure $4 \mathrm{a}$ and Figure $4 \mathrm{~b}$ respectively.

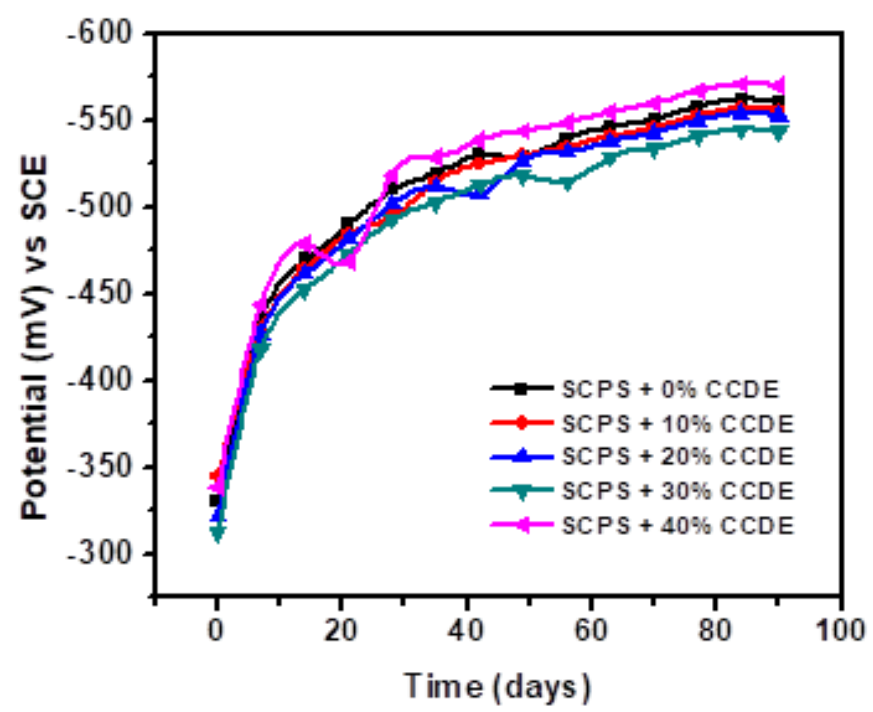

Figure 4a. Potential-time behavior of steel in SCPS with varying percentage of CCDE.

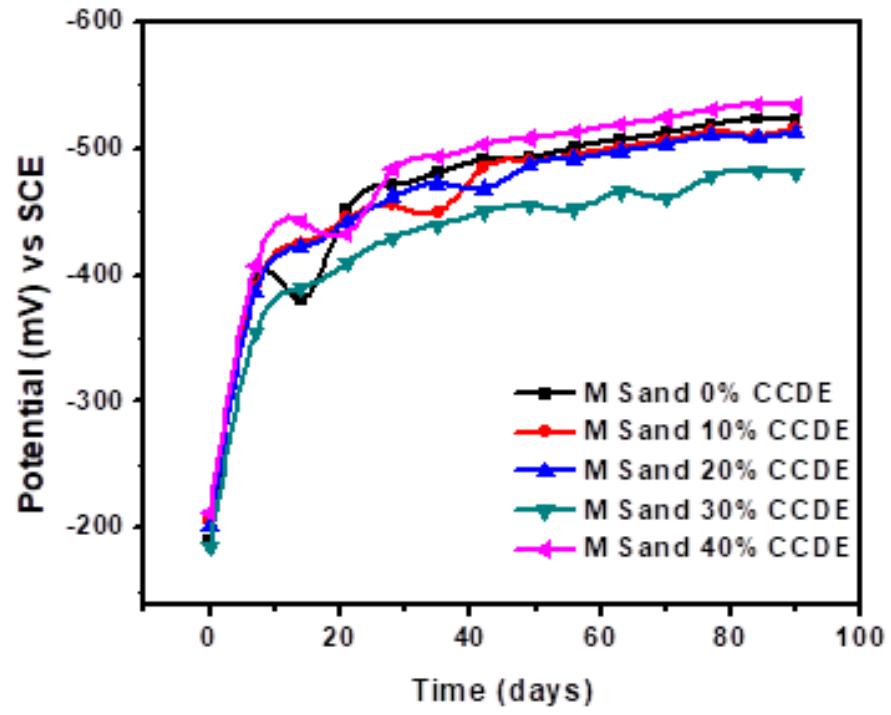

Figure 4b. Potential-time behavior of steel embedded in concrete with varying percentage of CCDE. 
Figure $4 \mathrm{a}$ shows the potential-time behavior of steel in SCPS $+3.5 \% \mathrm{NaCl}$ with varying percentages of CCDE $(0 \%, 10 \%, 20 \%, 30 \%$, and $40 \%)$ for the exposure period of 90 days. It was observed from Figure 4a that the OCP of steel is cathodically shifted throughout the exposure period. Initially, the OCP of steel was $-561 \mathrm{mV},-556 \mathrm{mV},-553 \mathrm{mV},-544 \mathrm{mV}$ and $-570 \mathrm{mV}$ in SCPS $+3.5 \% \mathrm{NaCl}$, SCPS $+3.5 \% \mathrm{NaCl}$ with $10 \%, 20 \% 30 \%$ and $40 \%$ of CCDE, respectively. The OCP of steel in SCPS $+3.5 \% \mathrm{NaCl}$ with $30 \%$ of CCDE was $-544 \mathrm{mV}$. It indicates that the CCDE up to $30 \%$ is to minimize the corrosion of steel in chloride-contaminated SCPS compared to SCPS $+3.5 \% \mathrm{NaCl}$ with $40 \% \mathrm{CCDE}$.

Figure $4 \mathrm{~b}$ shows the potential-time behavior of steel in embedded concrete with various percentages of CCDE $(0 \%, 10 \%, 20 \%, 30 \%$, and $40 \%)$ and which is exposed to $3.5 \% \mathrm{NaCl}$ solution over a period of 90 days. In this process, alternate wet and dry cycles were performed to accelerate the corrosion process. One cycle consists of 3 days of wetting in chloride solution and 3 days drying in an open atmosphere at room temperature. It was observed from Figure $4 \mathrm{~b}$ that passivity of steel was maintained up to $30 \%$ of CCDE throughout the exposure period. CCDE is admixed into concrete during the casting process; hence the organic inhibitor molecules are directed towards the steel surface from day one onwards. However, chloride ions in concrete tend to become complex and exist in three forms, namely physically adsorbed chlorides, complex chlorides, and free chlorides. Only free chlorides are move towards steel and accelerate the corrosion process. In our studies, CCDE able to form a compact barrier film on the steel surface before chloride ions move towards to steel. Hence a perfect passivity is formed between CCDE and steel interfacial region.

\subsubsection{Potentiodynamic polarization}

The potentiodynamic polarization of rebar in SCPS and embedded in concrete with various concentrations of CCDE is shown in Figure 5a and Figure 5b, respectively. From Figure 5a, it was observed that the corrosion current density values are reduced up to $30 \% \mathrm{CCDE}$. The reduction in the corrosion rate for various systems follows the order:

\section{$30 \% \mathrm{CCDE}>20 \% \mathrm{CCDE}>10 \% \mathrm{CCDE}>40 \% \mathrm{CCDE}>$ Control}

The coconut coir dust extracts act as a mixed-type inhibitor with predominantly cathodic type. From Figure 5b, the corrosion rate of rebar embedded in concrete follows the same order as already observed in solution studies. 


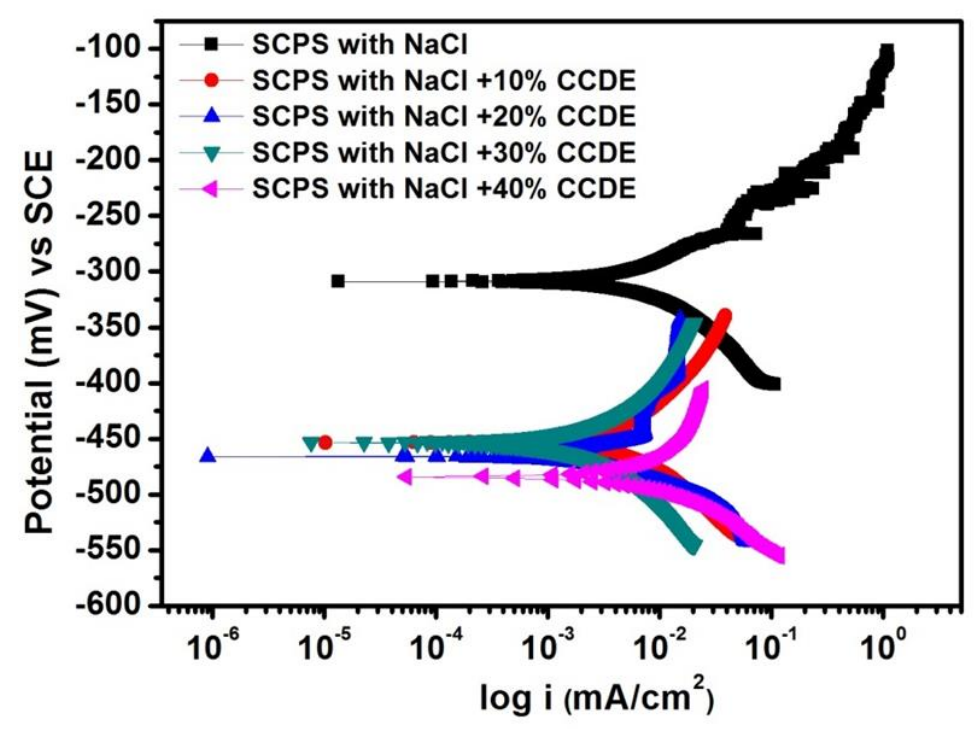

Figure 5a. Polarization curves for rebars exposed to SCPS with varying percentage of CCDE.

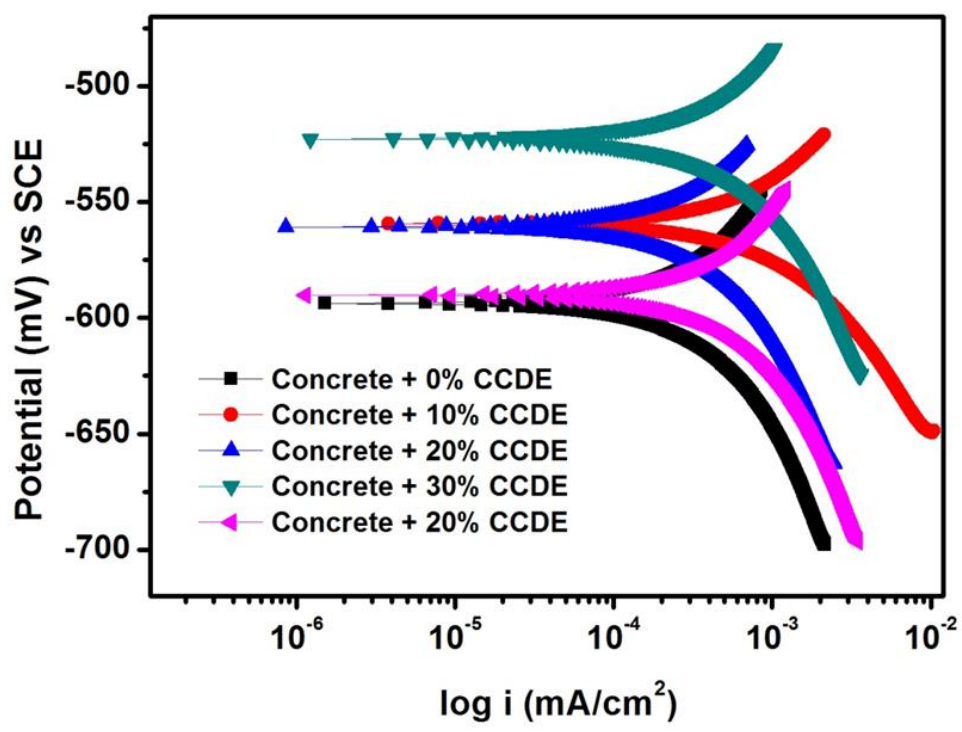

Figure 5b. Polarisation curves for rebar embedded in concrete with varying percentage of CCDE.

\subsubsection{AC-Impedance spectra}

The Nyquist plots for rebar in SCPS with various concentrations of CCDE are shown in Figure 5a. The EIS technique provides a means of characterizing electrode processes and complex interfaces. It is ideal for studying the system response to applying a periodic small amplitude AC signal. Figure 6a shows the Nyquist diagrams of steel in concrete pore solution without and with selected concentrations of coconut coir dust extract. It is clear from Figure 6 that the charge transfer resistance values increase up to 30\% CCDE. On the other hand, the double-layer capacitance values decrease up to $30 \% \mathrm{CCDE}$. Here again, it 
was proved that the inhibitor CCDE performed better up to $30 \%$. Bode (Figure 6c) and phase (Figure 6d) impedance plot shown in indicate that the difference of impedance at high frequency and low frequency is higher for 30\% CCDE than 10\%, 20\%, and 40\% CCDE.

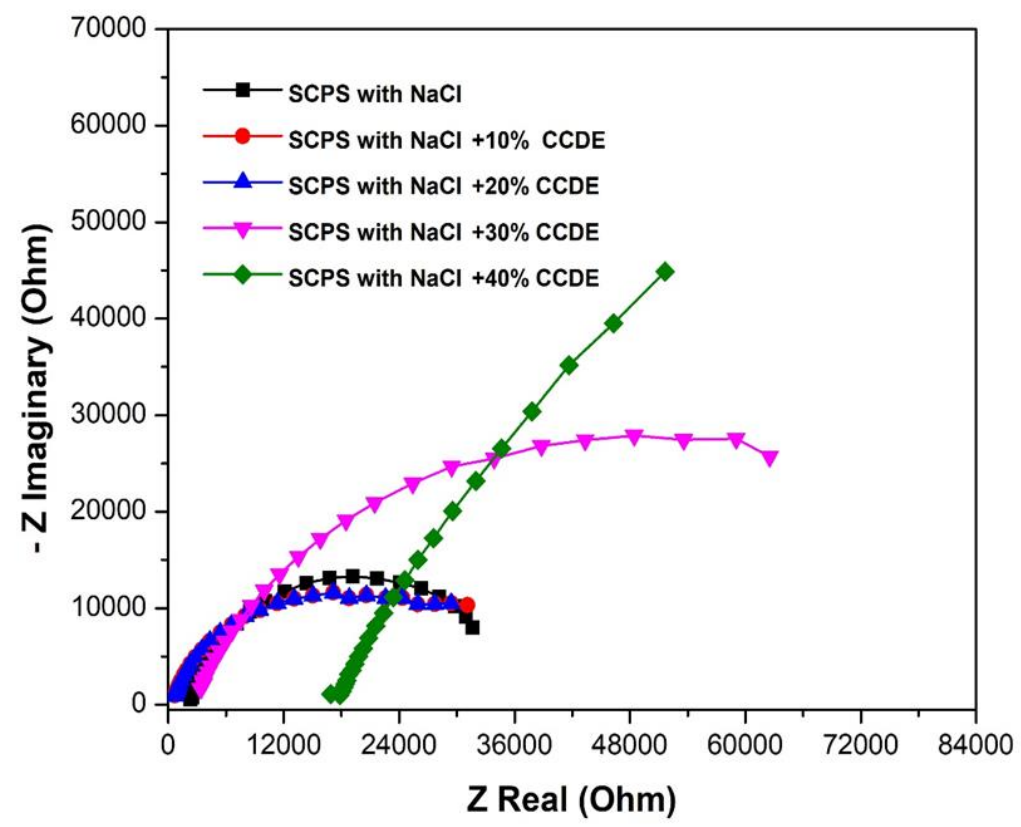

Figure 6a. Nyquist plots for rebar exposed to SCPS with varying percentage of CCDE.

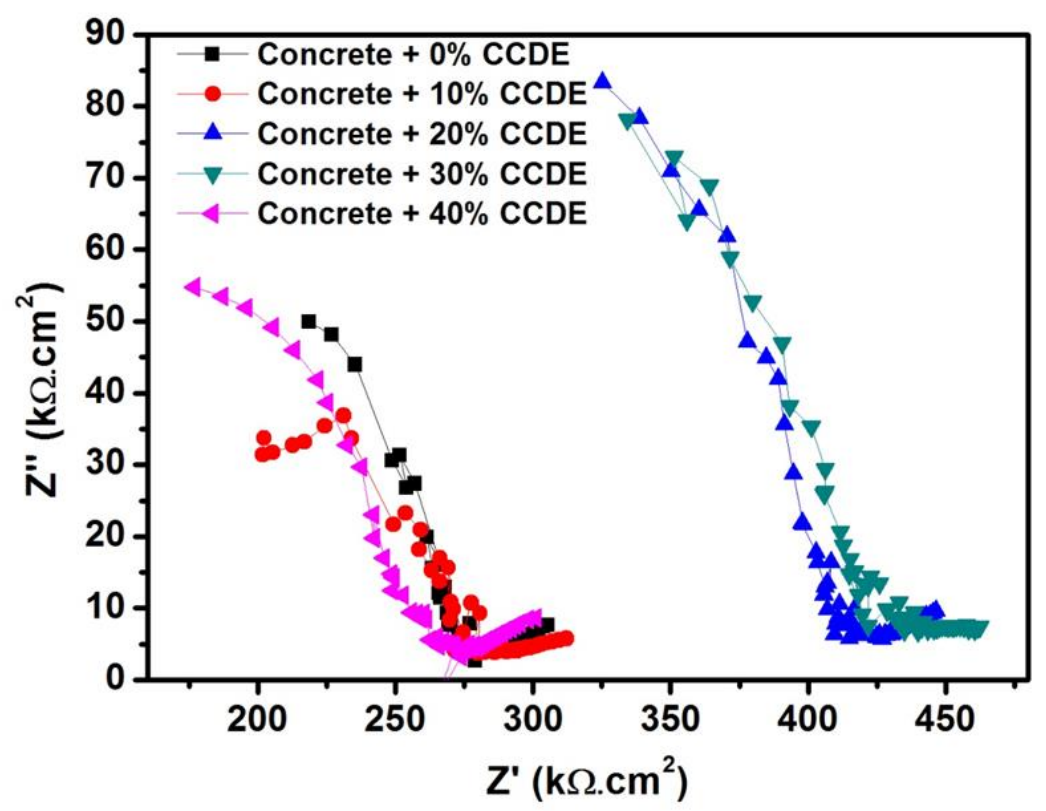

Figure 6b. Nyquist plots for rebar embedded in concrete with varying percentage of CCDE. 


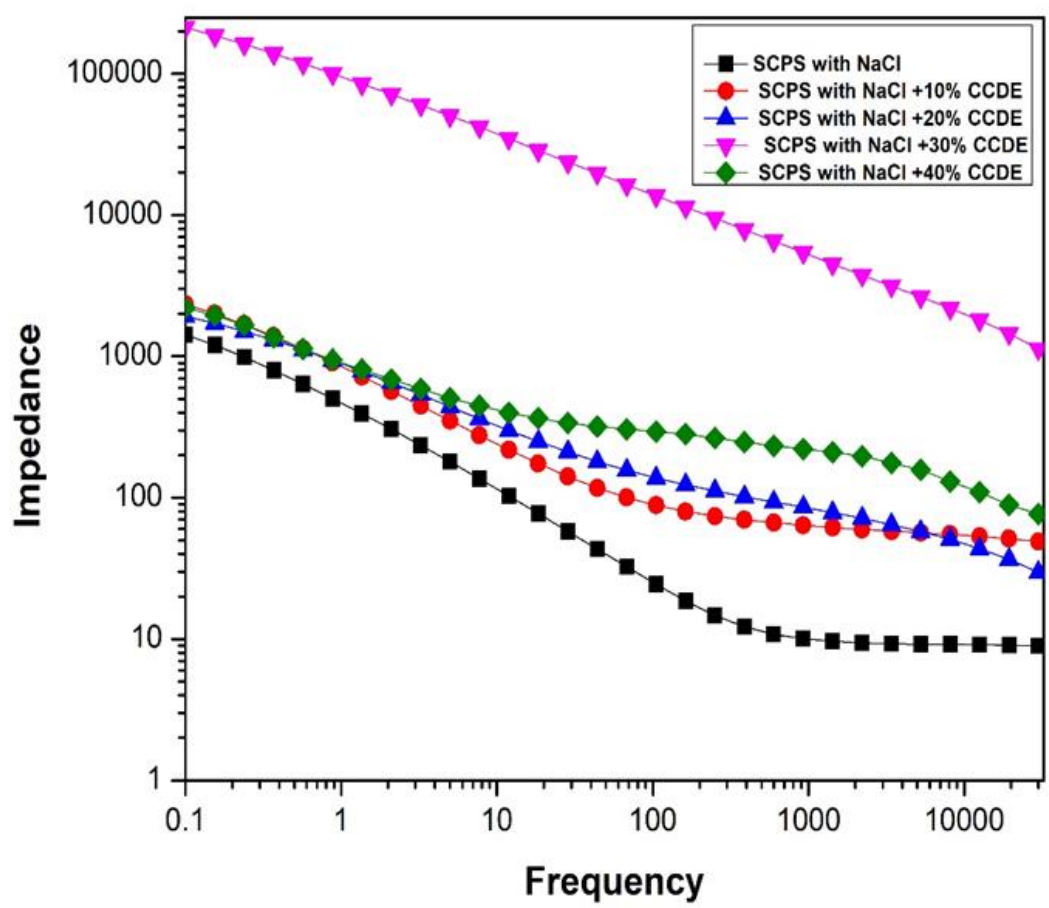

Figure 6c. Bode impedance plot.

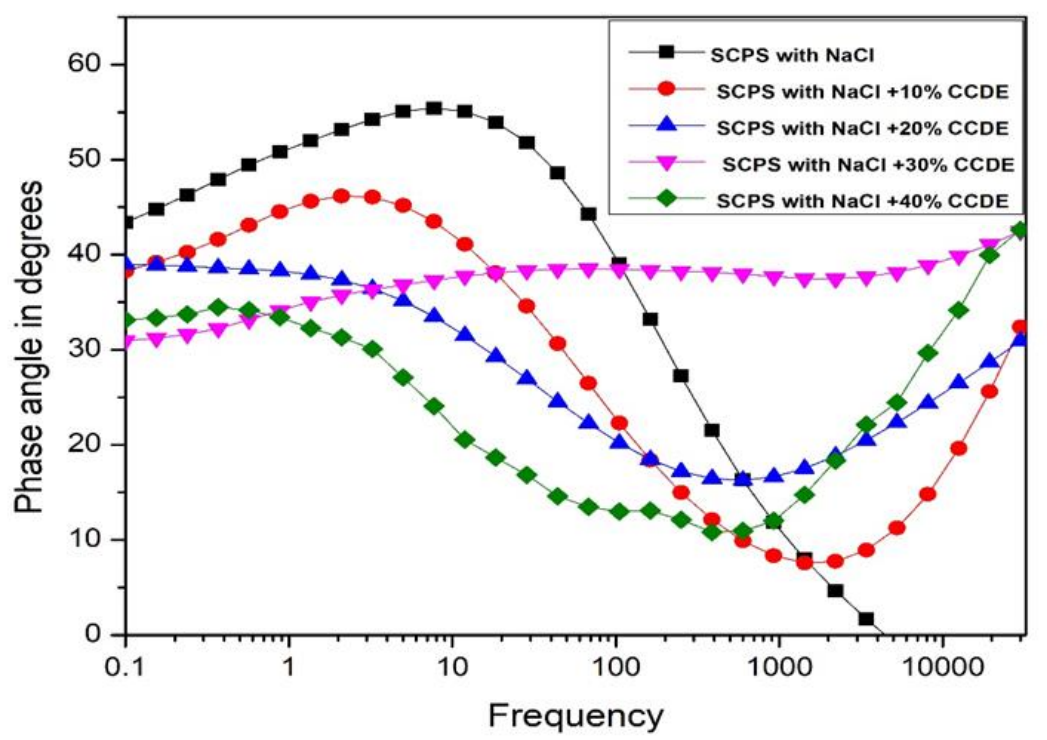

Figure 6d. Bode phase plot. 


\subsection{FTIR spectra}

Figure 7(a,b) shows the FTIR spectra of steel-concrete interface for concrete with $30 \% \mathrm{CCDE}$ and the dry recorded spectrum of CCDE. The peak at $3434.38 \mathrm{~cm}^{-1}$ (associated hydroxyl) was overlapped by the strong stretching mode of $\mathrm{N}-\mathrm{H}$. The $1634.17 \mathrm{~cm}^{-1}$ band is corresponding to the $\mathrm{N}-\mathrm{H}$ bend. The peak at $1262.22 \mathrm{~cm}^{-1}$ can is assigned to the stretching mode of $\mathrm{C}-\mathrm{N}$ group. The band at $1453.93 \mathrm{~cm}^{-1}$ is attributed to $\mathrm{C}-\mathrm{C}$ in the ring (for aromatic). These results show the presence of coconut extract contains a mixture of compounds, i.e., alkaloids and flavonoids. It can also appear on the steel-concrete interface and inhibit the corrosion of steel. A comparison of the FTIR spectra shown in Figure 7a and Figure $7 \mathrm{~b}$ supports the adsorption of the corrosion inhibitor on the metallic substrate.
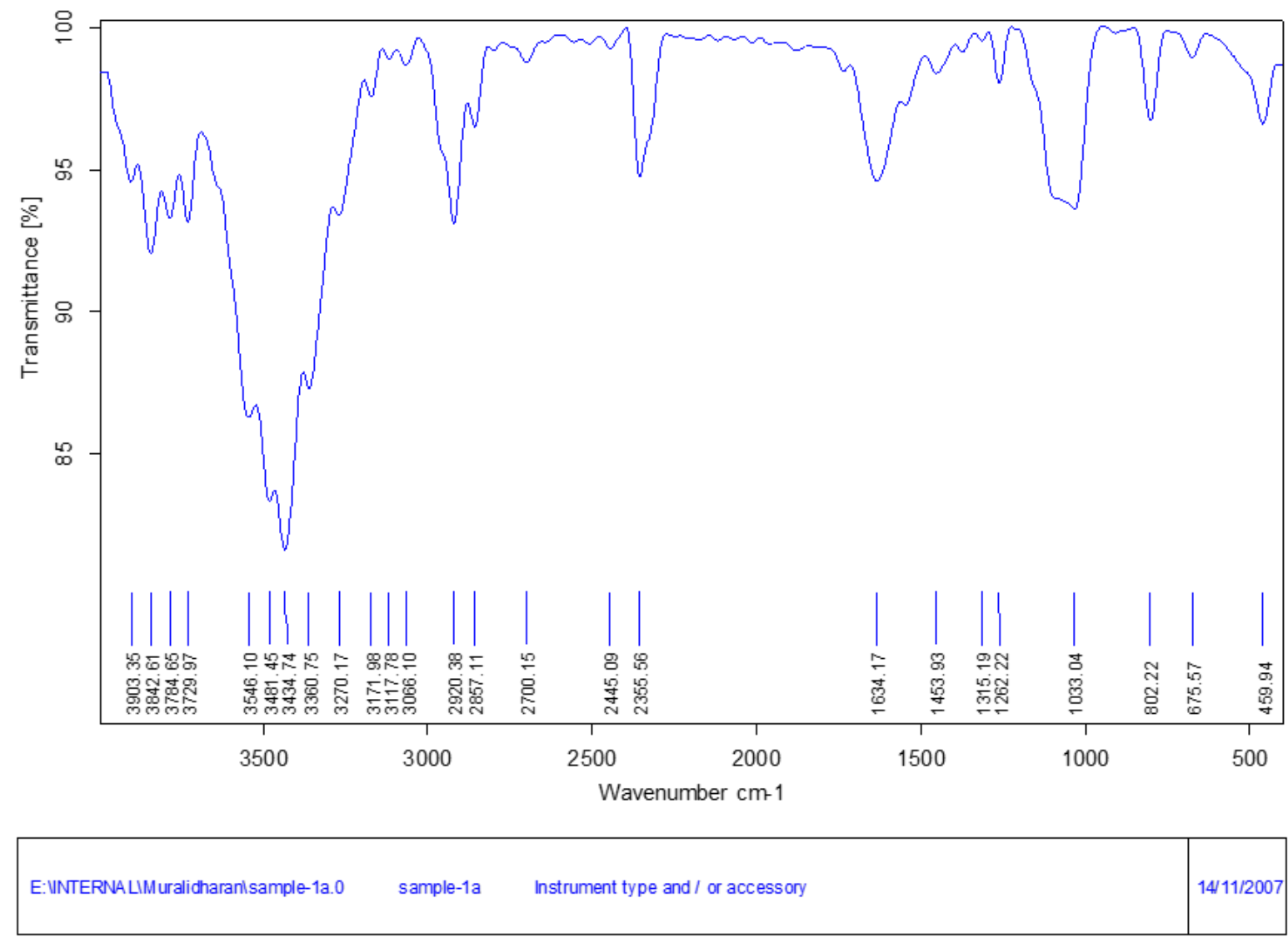

Page 1/1

Figure 7a. FTIR spectrum for steel concrete interface of 30\% CCDE admixed concrete. 


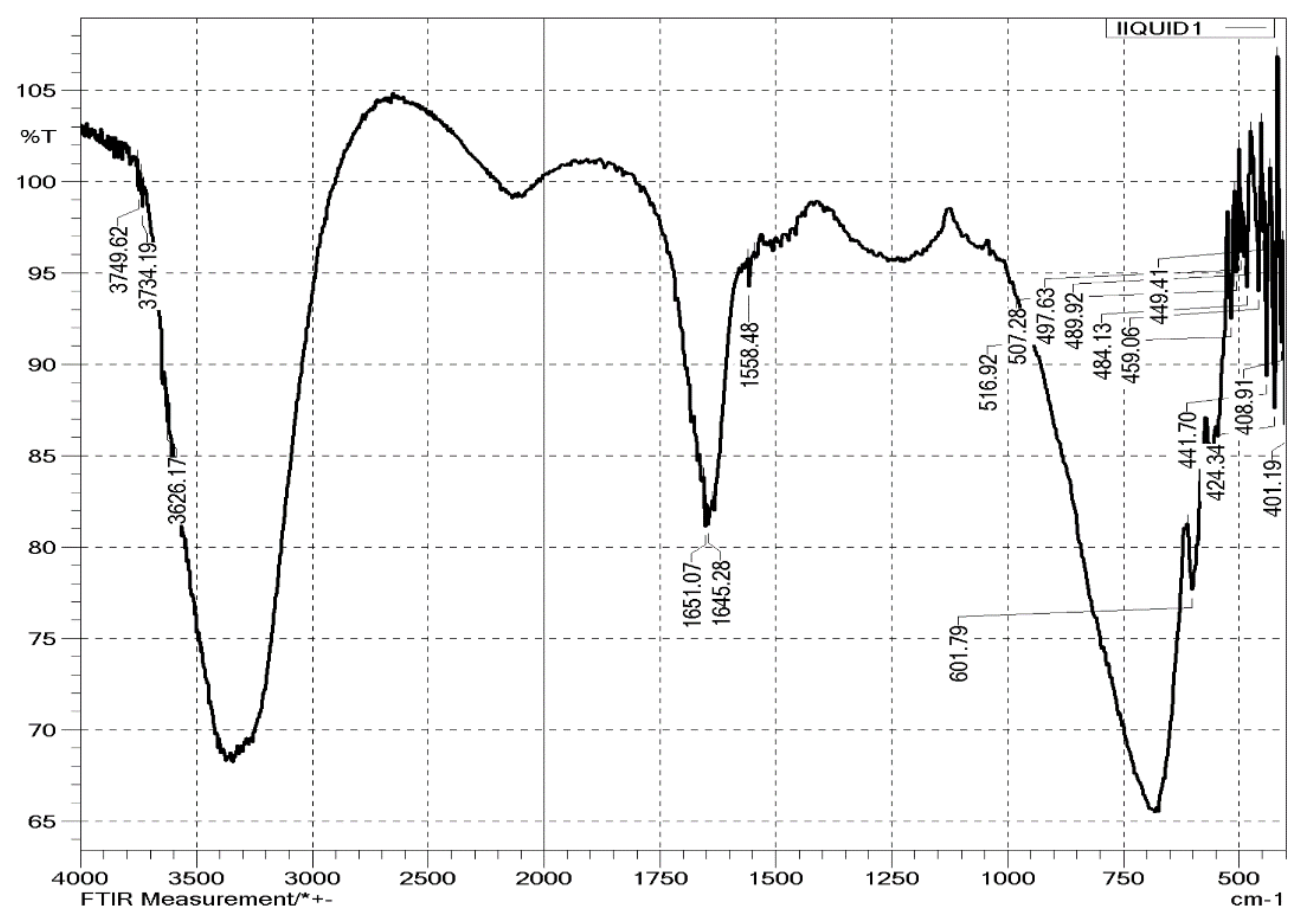

Figure 7b. Dry Record Spectrum of CCDE extract.

\section{Conclusion}

The following conclusions can be drawn from the present investigation.

- Coconut Coir Dust Extract has been used for the first time as a corrosion inhibitor for rebar in concrete.

- Weight loss measurement revealed that CCDE able to provide more than $95 \%$ inhibition efficiency even in $3.5 \% \mathrm{NaCl}$ solution.

- The addition of CCDE up to $40 \%$ does not affect the mechanical property of concrete.

- 30\% of CCDE admixed in concrete showed better corrosion resistance properties.

- Potentiodynamic polarization studies indicated that the inhibitor CCDE act as a mixed type and predominantly cathodic.

- EIS studies showed that 30\% CCDE in SCPS and also in concrete showed better corrosion resistance.

- FTIR spectra confirmed the adsorption of organic molecules on the steel surface and thereby provided the inhibition.

- CCDE is a good candidate greener inhibitor for corrosion of steel in concrete because CCDE not only increases the compressive strength but also reduce the self corrosion of steel to the maximum extent.

\section{Acknowledgments}

Authors thank The Principal and Management of PSG College of Technology, Coimbatore, Tamilnadu, India for kind permission to publish the paper. 


\section{References}

1. I. Merimi, R. Touzani, A. Aouniti, A. Chetouani and B. Hammouti, Pyrazole derivatives efficient organic inhibitors for corrosion in aggressive media: A comprehensive review, Int. J. Corros. Scale Inhib., 2020, 9, no. 4, 1237-1260. doi: 10.17675/2305-6894-20209-4-4

2. Yu.I. Kuznetsov, Progress in the science of corrosion inhibitors, Int. J. Corros. Scale Inhib., 2015, 4, no. 1, 15-34. doi: 10.17675/2305-6894-2015-4-1-015-034

3. M.A. Quraishi, D.S. Chauhan and V.S. Saji, Heterocyclic Organic Corrosion Inhibitors: Principles and Applications, Elsevier Inc., Amsterdam, 2020. ISBN: 9780128185582; doi: 10.1016/B978-0-12-818558-2.00001-1

4. K.R. Ansari, S. Ramkumar, D.S. Chauhan, M. Salman, D. Nalini, V. Srivastava and M.A. Quraishi, Macrocyclic compounds as green corrosion inhibitors for aluminium: electrochemical, surface and quantum chemical studies, Int. J. Corros. Scale Inhib., 2018, 7, no. 3, 443-459. doi: 10.17675/2305-6894-2018-7-3-13

5. P. Dohare, D.S. Chauhan and M.A. Quraishi, Expired Podocip drug as potential corrosion inhibitor for carbon steel in acid chloride solution, Int. J. Corros. Scale Inhib., 2018, 7, no. 1, 25-37. doi: 10.17675/2305-6894-2018-7-1-3

6. M. Ormellese, M. Berra, F. Bolzoni and T. Pastore, Corrosion inhibitors for chlorides induced corrosion in reinforced concrete structures, Cem. Concr. Res., 2006, 36, 536547. doi: $10.1016 /$ j.cemconres.2005.11.007

7. T.A. Söylev and M. Richardson, Corrosion inhibitors for steel in concrete: State-of-theart report, Constr. Build. Mater., 2008, 22, 609-622. doi: 10.1016/j.conbuildmat.2006.10.013

8. S. John and A. Joseph, Electroanalytical studies of the corrosion-protection properties of 4-amino-4H-1,2,4-triazole-3, 5-dimethanol (ATD) on mild steel in $0.5 \mathrm{~N}$ sulfuric acid, Res. Chem. Intermed., 2012, 38, 1359-1373. doi: 10.1007/s11164-011-0468-7

9. I. Obot, N. Obi-Egbedi and A. Eseola, Anticorrosion potential of 2-mesityl-1H-imidazo $[4,5-f][1,10]$ phenanthroline on mild steel in sulfuric acid solution: experimental and theoretical study, Ind. Eng. Chem. Res., 2011, 50, 2098-2110. doi: 10.1021/ie102034c

10. A. Abdulrahman, M. Ismail and M.S. Hussain, Corrosion inhibitors for steel reinforcement in concrete: A review, Sci. Res. Essays, 2011, 6, 4152-4162. https://staff.futminna.edu.ng/MME/content/journal/PF1380/24.pdf

11. X. Shi, Z. Yang, T.A. Nguyen, Z. Suo, R. Avci and S. Song, An electrochemical and microstructural characterization of steel-mortar admixed with corrosion inhibitors, Sci. China, Ser. E: Technol. Sci., 2009, 52, 52-66. doi: 10.1007/s11431-008-0276-5

12. J.M. Gaidis, Chemistry of corrosion inhibitors, Cem. Concr. Compos., 2004, 26, 181189. doi: $10.1016 /$ S0958-9465(03)00037-4

13. P.B. Raja and M.G. Sethuraman, Atropine sulphate as corrosion inhibitor for mild steel in sulphuric acid medium, Mater. Lett., 2008, 62, 1602-1604. doi: $\underline{10.1016 / \text { j.matlet.2007.09.032 }}$ 
14. P.B. Raja and M.G. Sethuraman, Natural products as corrosion inhibitor for metals in corrosive media - a review, Mater. Lett., 2008, 62, 113-116. doi: 10.1016/j.matlet.2007.04.079

15. S.A. Asipita, M. Ismail, M.Z. Abd Majid, Z.A. Majid, C. Abdullah and J. Mirza, Green Bambusa Arundinacea leaves extract as a sustainable corrosion inhibitor in steel reinforced concrete, J. Cleaner Prod., 2014, 67, 139-146. doi: 10.1016/j.jclepro.2013.12.033

16. S. Palanisamy, G. Maheswaran, C. Kamal and G. Venkatesh, Prosopis juliflora - A green corrosion inhibitor for reinforced steel in concrete, Res. Chem. Intermed., 2016, 42, 7823-7840. doi: 10.1007/s11164-016-2564-1

17. N. Odewunmi, S. Umoren and Z. Gasem, Utilization of watermelon rind extract as a green corrosion inhibitor for mild steel in acidic media, J. Ind. Eng. Chem., 2015, 21, 239-247. doi: $10.1016 /$ j.jiec.2014.02.030

18. S. Palanisamy, G. Maheswaran, A.G. Selvarani, C. Kamal and G. Venkatesh, Ricinus communis-A green extract for the improvement of anti-corrosion and mechanical properties of reinforcing steel in concrete in chloride media, J. Build. Eng., 2018, 19, 376-383. doi: 10.1016/j.jobe.2018.05.020

19. S.A. Umoren, M.M. Solomon, U.M. Eduok, I.B. Obot and A.U. Israel, Inhibition of mild steel corrosion in $\mathrm{H}_{2} \mathrm{SO}_{4}$ solution by coconut coir dust extract obtained from different solvent systems and synergistic effect of iodide ions: Ethanol and acetone extracts, J. Environ. Chem. Eng., 2014, 2, 1048-1060. doi: 10.1016/j.jece.2014.03.024

20. N. Chaubey, A. Qurashi, D.S. Chauhan and M. Quraishi, Frontiers and advances in green and sustainable inhibitors for corrosion applications: A critical review, J. Mol. Liq., 2020, 114385. doi: 10.1016/j.molliq.2020.114385

21. J.A. Selvi, M. Arthanareeswari, T. Pushpamalini, S. Rajendran and T. Vignesh, Effectiveness of Vinca rosea leaf extract as corrosion inhibitor for mild steel in $1 \mathrm{~N} \mathrm{HCl}$ medium investigated by adsorption and electrochemical studies, Int. J. Corros. Scale Inhib., 2020, 9, 1429-1443. doi: 10.17675/2305-6894-2020-9-4-15

22. W. Chen, R.-G. Du, C.-Q. Ye, Y.-F. Zhu and C.-J. Lin, Study on the corrosion behavior of reinforcing steel in simulated concrete pore solutions using in situ Raman spectroscopy assisted by electrochemical techniques, Electrochim. Acta, 2010, 55, 5677-5682. doi: 10.1016/j.electacta.2010.05.003

23. S. Umoren, U. Eduok, A. Israel, I. Obot and M. Solomon, Coconut coir dust extract: a novel eco-friendly corrosion inhibitor for $\mathrm{Al}$ in $\mathrm{HCl}$ solutions, Green Chem. Lett. Rev., 2012, 5, 303-313. doi: $\underline{10.1080 / 17518253.2011 .625980}$ 